\title{
Characterization and Phylodiversity of Implicated Enteric Bacteria Strains in Retailed Tomato (Lycopersicon esculentum Mill.) Fruits in Southwest Nigeria
}

Yemisi Dorcas Obafemi $^{1 *}$, Paul Akinniyi Akinduti ${ }^{1}$, Adesola Adetutu Ajayi ${ }^{2}$, Patrick Omoregie Isibor ${ }^{1}$, Theophilus Aanuoluwa Adagunodo ${ }^{3}$

${ }^{1}$ Department of Biological Sciences, Covenant University, PMB 1023, Ota, Ogun State, Nigeria; ${ }^{2}$ Department of Biological Sciences, Augustine University, PMB 1010, Epe, Lagos State, Nigeria; ${ }^{3}$ Department of Physics, Covenant University, PMB 1023, Ota, Ogun State, Nigeria

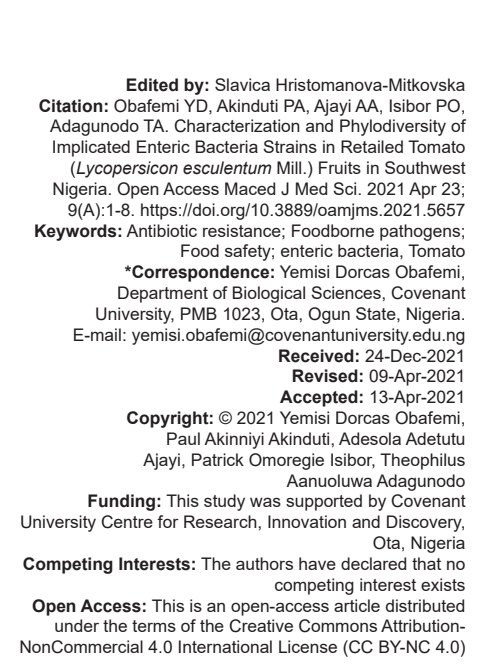

Abstract

BACKGROUND: Tomatoes (Lycopersicon esculentum Mill.) have very huge health-promoting benefits due to high nutritional composition; however, these fruits are potential reservoir of enteric food-borne pathogens causing major public health concerns.

AIM: Characterization and phylo-analysis of implicated enteric bacteria strains in retailed Tomato fruits in southwest Nigeria were studied.

METHODS: Ready to be retailed fresh tomato fruits were purchased from common food markets in southwest Nigeria, which lies between latitudes $6^{\circ} 21^{\prime}$ to $8^{\circ} 30^{\prime} \mathrm{N}$ and longitudes $2^{\circ} 30^{\prime}$ to $5^{\circ} 30^{\prime} \mathrm{E}$. Observation of sample storage potentials at different conditions and bio-typing of associated bacterial strains were carried out for consecutive 14 days. Enteric bacteria strains were genotyped with $16 \mathrm{~S}$ rRNA assay and further profiled for antibiotic susceptibility to common antibiotics. High population rate frequently consume tomatoes.

RESULTS: Early spoilage characterized with yellow fluid, fungal growth and visible lesions were observed at $25^{\circ} \mathrm{C}$ storage compare to few patches of lesion at $4^{\circ} \mathrm{C}$ after 14 days. Higher bacterial count of $4.0-7.18 \mathrm{Log} \mathrm{CFU} / \mathrm{g}$ was recorded at ambient storage compare to refrigerated samples with more than $10 \%$ occurrence rate of Citrobacter spp., Klebsiella spp. and Enterobacter spp. Identified Citrobacter spp. and Klebsiella spp. showed 100\% resistant to beta-lactam antibiotics (ceftazidime, cefuroxime, cefixime, ciprofloxacin, and amoxicillin-clavulanic acid). Tworesistant enteric bacteria strains, Klebsiella aerogenes B18 and Citrobacter freundii B27 obtained from Nigerian tomato clustered with Citrobacter strains in food (China), water strains (India, Poland, Malaysia), milk (Germany), and human fecal (China)

CONCLUSION: Implicated multidrug-resistant enteric bacilli in retailed tomatoes can cause severe food-borne diseases which public oriented awareness, strategic farm to market surveillance are needed to be intensified.

\section{Introduction}

Tomato (Lycopersicon esculentum Mill.) belongs to a plant family known as Solanacea [1]. It is one of the most important fruits in the world which can be eaten raw or processed into paste or juice [2]. Tomato supplies about $90 \%$ of dietary Vitamin C needed for human nutrition with a high ascorbic acid and lycopene content [3], [4], [5]. In Africa, tomatoes are also used for medicinal purposes for protection against various diseases such as the osteoporosis, cardiovascular disorders, and prostate cancer [6]. Recent reports on the nutritional composition in tomatoes revealed $95 \%$ water and $4.5 \%$ carbohydrate with other natural nutrients such as vitamins, minerals, dietary fiber, and protein [7], [8]. The rich nutritional components of tomatoes are often exploited by microorganisms which make post-harvest tomato spoilage and contamination to be rampant [9], [10]. Post-harvest spoilage and contamination occur initially on protective outer surface after which movement of water into the fruits occur causing contamination and possible attacks by enteric pathogens [11]. Contamination of tomatoes may result from the treatment of the soil with organic fertilizers, such as sewage sludge and manure, irrigation water, as well as from water used in washing the tomatoes in the market till it gets to the final consumers [12]. In Nigeria, tomatoes are kept in the open markets often displayed in baskets or on benches for the prospective customers, thereby exposing them to opportunistic microbial infections [13]. Post-harvest infections in tomato could occur during storage, transportation, packaging, and distribution (loading and offloading) at various points of sale at which bacteria are present. Therefore, adequate knowledge and careful handling procedure of the tomatoes can reduce wastage of the fruits [14]. However, the incidence of foodborne disease is now becoming a public health issue considering the recent outbreaks of foodborne diseases in various 
countries due to consumption of contaminated raw fruits [15], [16], [17], [18]. The previous reports have implicated presence on pathogens on surfaces of fresh fruits and vegetables which includes Escherichia coli, Salmonella paratyphi typhi, Klebsiella pneumonia, Yersinia pestis, Shigella dysenteriae, and Listeria monocytogenes; however, there is still paucity of studies to determine the public health implication of consuming the contaminated tomatoes which are often used by many local food eateries in Nigeria [19], [20], [21], [22], [23]. There is need to determine bacteria contaminants in tomatoes and check their antimicrobial susceptibility to common content that may constitute risk to public health [24]. Reports are suggesting possible contamination of fresh edible tomatoes resulting in high microbial diversity including the family Enterobacteriaceae that invariable signifies poor post-harvest sanitation practices by the farmers and local handlers [25], [26], [27], 28], [29], [30]. Therefore, the prevailing enteric pathotypes and genotypes in retailed tomato fruits in Southwest Nigeria were studied.

\section{Materials and Methods}

\section{Sample collection and bacteria growth kinetics}

One hundred and twenty fresh tomato fruits were purchased from 18 major food markets in southwest Nigeria between April and June 2017 and transported in the cold chain. Accurate coordinates of the sampling markets were recorded with the Global Positioning System device, as described by Obeng et al. [31]. Each tomato sample batch was assayed for spoilage bacteria growth kinetics by $2 \times 2$ contingency factorial design of each group of 60 samples each at various ambient temperatures $\left(25^{\circ} \mathrm{C}\right)$ and refrigerated condition $\left(4^{\circ} \mathrm{C}\right)$ experimental design. These selected temperatures are the common condition of storage in many households in Nigeria and all the samples in each conditional group were daily analyzed for bacteria growth kinetics for a period of 14 days while evidence for visible lesion was observed during deterioration stages.

\section{Viable bacteria count and phenotypic characterization}

At each successive day of the storage, $1 \mathrm{~g}$ of mashed tomato sample from each experimental condition was thoroughly grounded and homogenized in $9 \mathrm{ml}$ sterile water, serially diluted, inoculated into brain heart infusion agar and incubated at $37^{\circ} \mathrm{C}$ for $24 \mathrm{~h}$. Total bacteria colonies were enumerated and phenotypically biotyped with the taxonomic scheme of Bergey's Manual of Determinative Bacteriology [32].

\section{Antimicrobial susceptibility assay}

Characterized bacterial strains were profiled for an antibiogram using the Kirby-Bauer disc diffusion method [33]. Briefly, the broth culture of 0.5 MacFarland turbidity was spread on Muller-Hilton Agar. The antibiotic disc of Ceftazidime $(30 \mu \mathrm{g})$, Cefuroxime $(30 \mu \mathrm{g})$, cefixime $(30 \mu \mathrm{g})$, ofloxacin $(5 \mu \mathrm{g})$, ciprofloxacin $(5 \mu \mathrm{g})$, Gentamicin $(10 \mu \mathrm{g})$, nitrofurantoin $(30 \mu \mathrm{g})$, and augmentin $(30 \mu \mathrm{g})$ was added and incubated at $37^{\circ} \mathrm{C}$ for $24 \mathrm{~h}$. The zone of inhibition obtained was measured and evaluated [34].

\section{Genotyping}

The chromosomal DNA of each bacteria isolates was extracted (Jena $\mathrm{JmbH}$, Germany) and amplified for 16S rRNA using previously described polymerase chain reaction (PCR) assay [35]. Amplification was carried out in a Hybaid PCR express unit (Hybaid Ltd., Middlesex, UK) at initial denaturation temperature of $94^{\circ} \mathrm{C}$ for $5 \mathrm{~min}$ for 1 cycle which was followed by 30 cycles of denaturation at $95^{\circ} \mathrm{C}$ for $1 \mathrm{~min}$. Annealing at $55^{\circ} \mathrm{C}$ for $45 \mathrm{~s}$ and extension was at $72^{\circ} \mathrm{C}$ for 1 min. Final extension was carried out at $72^{\circ} \mathrm{C}$ for $7 \mathrm{~min}$ (Table 1). Primer pair used for this study was 27F:5'-AGAGTTTGATCCTGGCTCAG-3', and 1492R: 5'-GGTTACCTTGTTACGACTT-3'. Amplicons were separated on a $1.5 \%$ Agarose gel and electrophoresis carried out at 120 Volts for $40 \mathrm{~min}$ with the DNA ladder (Solis Biodyne), visualized with ultraviolet photo-documentation. Amplicons were purified using the QIAquick PCR purification kit (Qiagen, USA) and quantified with Thermoscientific Nanodrop Spectrophotometer at an absorbance of $260 \mathrm{~nm}$ to obtain required dilution of amplicon for sequencing. Purified products were sequenced using $A B I$ Prism Big Dye Terminator version 3.0, and products were subsequently analyzed on ABI PRISM 3700 DNA Analyzer. Obtained nucleotide reads were aligned into Basic Local Alignment Search Tool Web-based tool of the National Institutes of Health (USA) software to search for homologous sequences with not more $99 \%$ identity [36].

Table 1: Amplification condition used for PCR carried out in the study

\begin{tabular}{llll}
\hline Procedure & Temperature $\left({ }^{\circ} \mathrm{C}\right)$ & Time $($ seconds) & Number of cycles \\
\hline Initial denaturation & 94 & 300 & 1 \\
Denaturation & 95 & 60 & \\
Annealing & 55 & 45 & 30 \\
Extension & 72 & 60 & \\
Final extension & 72 & 420 & 1 \\
\hline PCR: Polymerase chain reaction & &
\end{tabular}

\section{Phylogenetic analysis}

Each bacteria sequence reads were manually aligned to make a dendrogram tree with maximum parsimony regarding the sequences as independent, unordered, and equally weighted according to Fitch parsimony with a calculated bootstrap option for each 
node of 1000 replicates of heuristic search using MEGA software version 6 [37].

\section{Data analysis}

The significance of the viable count at different kinetic temperature conditions was determined using Chi-square at $p<0.05$, while categorical data were analyzed with descriptive statistical methods. Bacteria antibiogram profile significance was evaluated with ANOVA $(p<0.05)$.

\section{Results}

\section{Sampling of tomato fruits from food} markets

The tomato fruits were on display when purchased from 18 major food markets located at lat. $7.2571 \pm 1.500^{\circ}$ and long. $5.2058 \pm 1.5500^{\circ}$ (Figure 1) distributed in six states (Ekiti, Lagos, Ogun, Ondo, Osun, and Oyo) in Southwest, Nigeria, with approximate population of $27,534,432$ in 2006 (Table 2). Daily observation shows that early spoilage and rottenness were observed in tomato fruits stored at ambient temperature $\left(25^{\circ} \mathrm{C}\right)$ on day 5 while refrigerated samples $\left(4^{\circ} \mathrm{C}\right)$ remain fresh throughout the experimental period. After 5 days at both ambient and refrigerated temperatures, no visible lesion was observed in refrigerated samples but only fungal growth at $25^{\circ} \mathrm{C}$. Broken cell wall, production of yellow fluid and heavy fungal growth was observed at $25^{\circ} \mathrm{C}$ after 14 days.

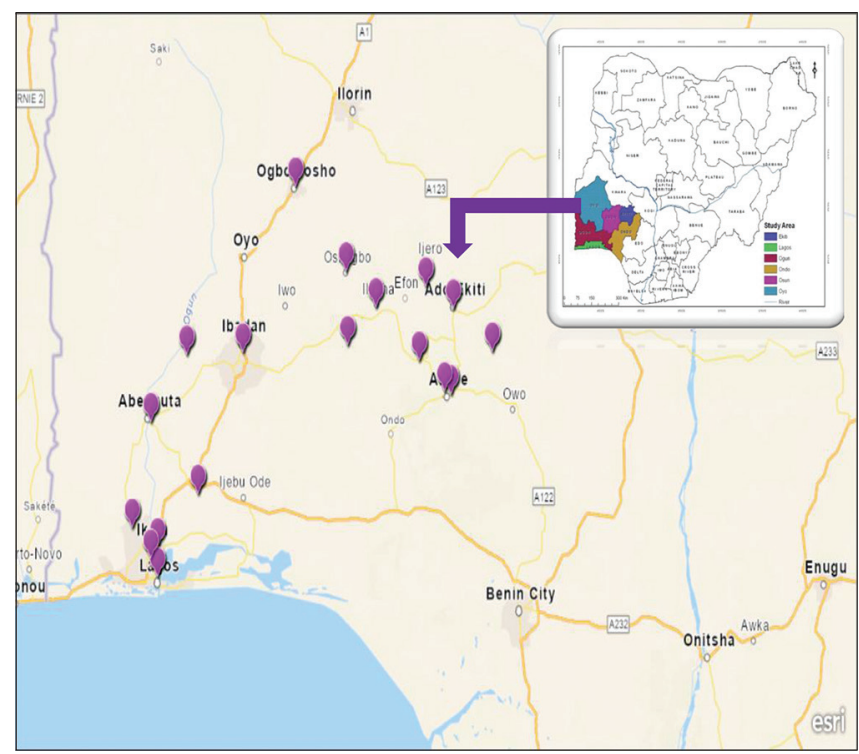

Figure 1: Geo-spatial distribution of sampled food markets in Southwest Nigeria
Table 2: Distribution of potential tomato consumers in various states in Southwest, Nigeria

\begin{tabular}{lll}
\hline Surveyed states & Area $\left(\mathrm{km}^{2}\right)$ & Population (persons) \\
\hline Ekiti & $6,353.00$ & $2,210,957.00$ \\
Lagos & $3,577.00$ & $9,113,605.00$ \\
Ogun & $16,980.55$ & $3,751,140.00$ \\
Ondo & $15,500.00$ & $3,460,877.00$ \\
Osun & $9,251.00$ & $3,416,959.00$ \\
Oyo & $28,454.00$ & $5,580,894.00$ \\
\hline
\end{tabular}

Map was designed using ArcGIS software online (https://www.arcgis.com/). Attribution: Esri, USGS | Esri, HERE, Garmin, METI/NASA, USGS.

\section{Viable bacteria count and phenotypic characterization}

The total bacterial count for tomato fruits stored at the ambient temperature was within the range of 4.0 $7.18 \mathrm{LogCFU} / \mathrm{g}$ and higher when compared with the refrigerated samples. However, steady rise in bacteria count was observed on day 8-10 of ambient

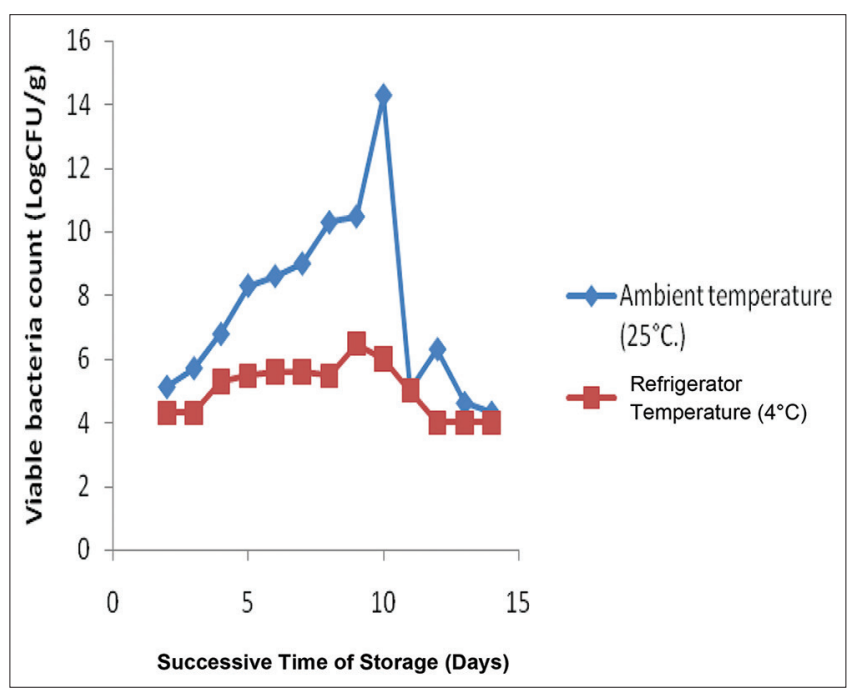

Figure 2: Successive viable bacteria count in different experimental conditions

storage indicating a very high spoilage rate than refrigerated samples (Figure 2). Occurrence of enteric bacteria isolates obtained was identified as Aeromonas spp. (2.6\%), Bacillus spp. (18.2\%), Citrobacter spp. (25.5\%), Proteus spp. (7.2\%), Klebsiella spp. (35.7\%), and Enterobacter spp. (10.8\%) (Figure 3).

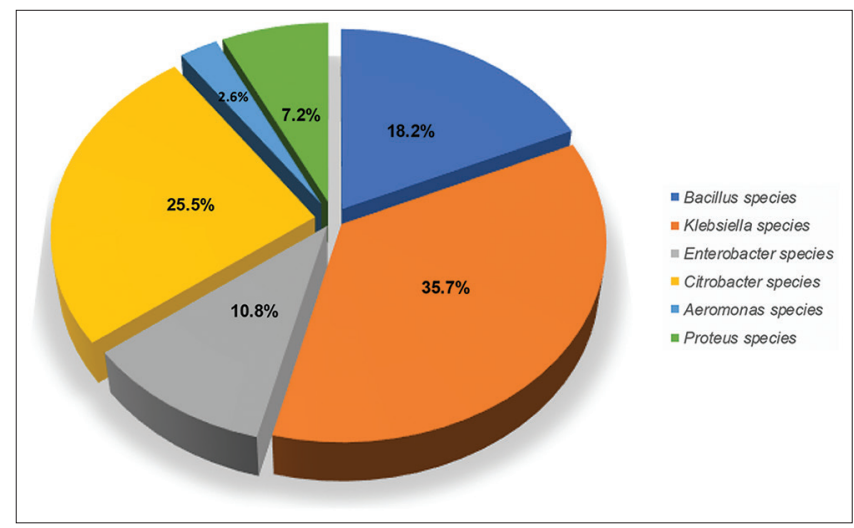

Figure 3: Occurrence of enteric bacilli in tomato fruits purchased from Southwest Nigeria $(n=120)$ 


\section{Antimicrobial susceptibility assay}

The antibiotic resistance profile of enteric bacteria strains from tomato fruits showed high multiantibiotic resistance particularly to commonly used betalactamase antibiotics such as ceftazidime, cefuroxime, cefixime, ciprofloxacin, and amoxicillin-clavulanic acid. A significantly low resistance was recorded rate for gentamycin, nitrofurantoin, and ofloxacin (Figure 4). High multidrug resistance rate observed in Citrobacter spp. (100\%) and Klebsiella spp. (100\%) to beta-lactam antibiotics.

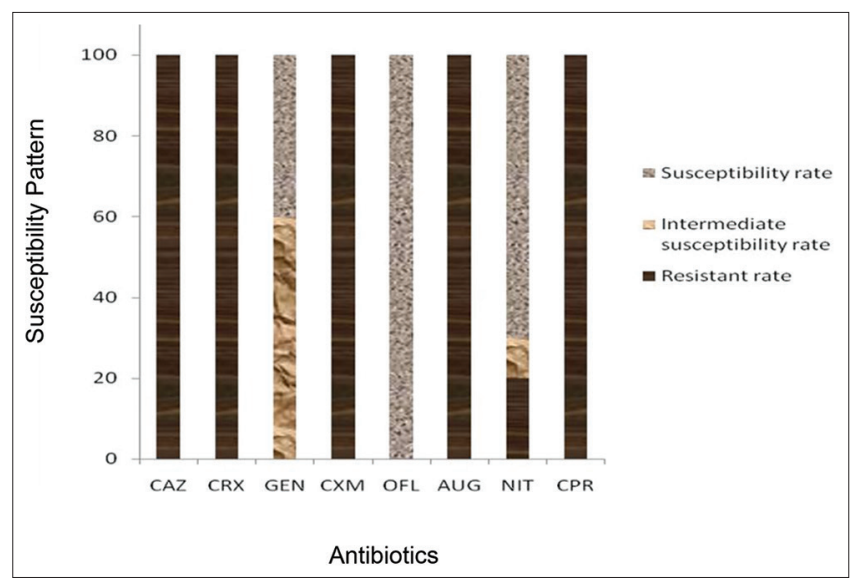

Figure 4: Susceptibility pattern of biotypes analyzed from tomato fruits. R: Resistant, I: Intermediate, S: Susceptible, CAZ: Ceftazidime, CRX: Cefuroxime, GEN: Gentamycin, CXM: Cefuroxime, OFL: Ofloxacin, AUG: Augmentin, NIT: Nitrofurantoin, CPR: Ciprofloxacin

\section{Genotyping and phylogenetic analysis}

The extracted and purified DNA yield was $5 \mathrm{ng}-25 \mathrm{ng}$ and the absorbance ratio $\left(\mathrm{A}_{260} / \mathrm{A}_{280}\right) 1.60$ 1.80 which informed constitution for PCR analysis using conditions presented in Table 1. Amplicon from the strains expressed high molecular weight band on Agarose gel (Figure 5). Two-resistant enteric bacteria strains were characterized as Klebsiella aerogenes B18

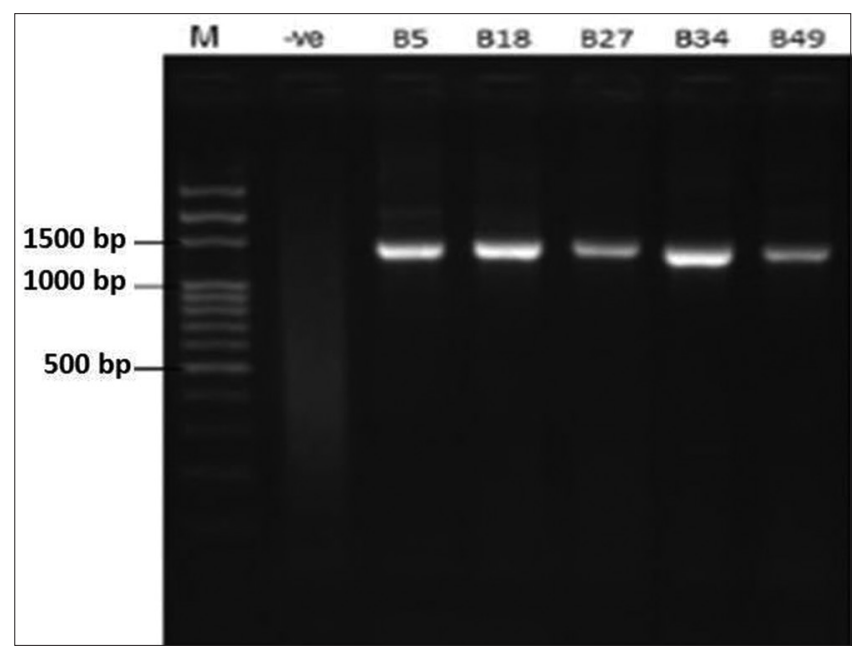

Figure 5: Amplicons of enteric bacterial strains expressed on Agarose gel (M - 500bp DNA Ladder, -ve: Negative Control, B5: Bacillus sp.; B18: Klebsiella sp.; B27: Citrobacter sp.; B34: Enterobacter sp. B49: Aeromonas sp.). and Citrobacter freundii B27. Both Citrobacter freudii from Nigerian tomato clustered with Citrobacter strains in food (China), water strains (Indian, Poland, Malaysia), milk (Germany), and human (China) while Klebsiella aerogenes showed genetical relatedness with other Citrobacter strains (red rectangular notch) (Figure 6).

\section{Discussion}

The tomato fruits are fresh farm products retailed in major food markets located in many cities in Southwest Nigeria. Residents in these areas are potential consumers who patronize the markets for fresh farm products including fruit retailers, food handlers, vendors, and canteen operators [38], [39], [40]. It is evidenced from the results that tomato fruits are well preserved at lower temperature below $8^{\circ} \mathrm{C}$, high humidity and could maintain its integrity as well as the nutritious value when compared to easily spoilt samples stored at ambient condition of $25^{\circ} \mathrm{C}$ [41], [42], [43]. High spoilage rate is expected considering the ubiquitous nature and optimum growth condition of many mesophilic bacteria which are mostly enteric pathogens transferred to the fruits during harvesting, storage, and transportation from farm to markets. Some of these strains could be pathogenic, causing various intestinal infections and severe enteric diseases particularly among the immune-compromised individuals. The previous studies reported 5-8 days of storage before for spoilage initiation is observed. This depends on environmental factors in preserving the post-harvest shelf life of tomato fruits because it has a tremendous influence on the rate of biological processes [44], [45]. Occurrence of enteric bacteria strains particularly coliforms suggests fecal contamination of tomato retailed in most of these markets, initiating spoilage, reduce post-harvest shelf life and increases gastrointestinal diseases due to poor hygiene and handling from farm to the markets. This agrees with previously published reports indicating six of the Gramnegative bacteria species isolated from the fruit samples could as fecal coliforms [46], [47], [48], [49], [50], [51]. Contamination of fresh tomatoes from the farm and in the market by enteric bacteria species including Escherichia coli and other coliforms were similarly reported in postharvest tomatoes in Nigeria [11]; Ghana [52], India [53], Europe, and USA [54], [55].

High multidrug resistance observed in Citrobacter spp. (100\%) and Klebsiella spp. (100\%) to beta-lactam antibiotics suggest an increase in use of antimicrobial agent for preservation and plant treatment resulting to acquisition of resistance in common food associated pathogens could intensify foodborne disease outbreak among the consumers. Occurrence of these resistant strains further suggests imminent danger of gastrointestinal disease outbreak from retailed tomato in most parts of southwest Nigeria. Poor post-harvest 


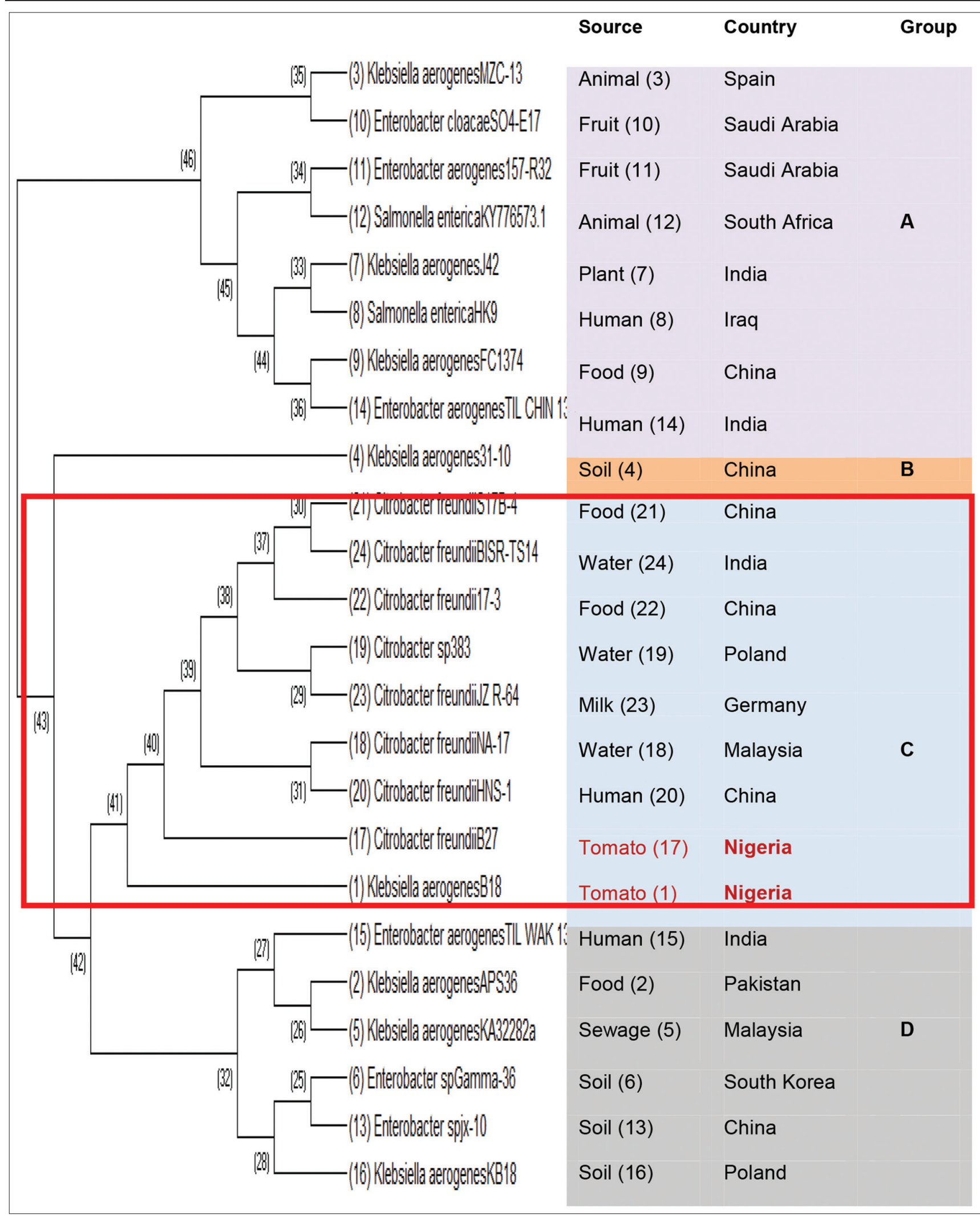

Figure 6: Phylogenetic diversity of 16s rRNA gene sequence of enteric bacteria strains in retailed Tomato fruits in Nigeria analyzed with GenBank reference

storage conditions of food materials, poor food handling practices, and unhygienic cooking habits in common street canteens and restaurants are gradually increasing resistant foodborne pathogens as well as other extended-spectrum beta-lactamases-producing strains in food materials in many communities [21], [56]. Clonal relatedness of highly resistant enteric Klebsiella aerogenes and Citrobacter freundii from Nigerian tomatoes with human, food, and milk products from other countries further indicate high genetic 
mobility and transfer from animal milk products, human contamination probably from fecal that could drive genetic reassortment leading to spread of phylo-diverse pathotypes [20], [57], [58], [59].

\section{Conclusion}

This study has established the fact that fresh tomato fruits serves as host to several bacteria pathogens that can cause food-borne diseases. Multidrug-resistant pathogens indicated potential causes of food borne infections and food contamination which is a major cause of public health concern. There is need for public awareness to prevent rising food contamination from tomatoes commonly called "Esa" in Nigeria which are fondly used by most food canteen operators and also to detect the new antimicrobial resistant strains using high throughput genomic techniques.

\section{Authors' Contributions}

YDO and AAA conceived and designed the background experiments in the study and collected the samples. PAA carried out all the isolation of the bacteria strains and antimicrobial sensitivity experiments. YDO carried out the phenotypic characterization of the bacterial strains with POI. The authors PAA and YDO carried out extraction, purification and quantification of DNA amplicon form the bacterial isolates. PAA carried out the PCR assay. TAA helped collection of samples and in drafting the manuscript figures and tables. All authors read and approved the final manuscript.

\section{Acknowledgments}

The authors appreciate the management of the Covenant University Centre for Research, Innovation and Discovery (CUCRID), Ota, Nigeria, for funding the publication of this research study and the contribution of the technical staff of the Department of Biological Sciences, Covenant University, Ota, Nigeria.

\section{References}

1. Angadi V, Rai PK, Bara BM. Effect of organic manures and biofertilizers on plant growth, seed yield and seedling characteristics in tomato (Lycopersicon esculentum Mill.). J Pharmacogn Phytochem. 2017;6(3):807-10.

2. Tan J, Kerr WL. Rheological properties and microstructure of tomato puree subject to continuous high-pressure homogenization. J Food Eng. 2015;166:45-54. https://doi. org/10.1016/j.jfoodeng.2015.05.025

3. Çolak NG, Eken NT, Ülger M, Frary A, Doğanlar S. Mapping of quantitative trait loci for antioxidant molecules in tomato fruit: Carotenoids, Vitamins $\mathrm{C}$ and $\mathrm{E}$, glutathione, and phenolic acids. Plant Sci. 2020;292:110393. https://doi.org/10.1016/j.plantsci.2019.110393 PMid:32005398

4. Chaudhary P, Sharma A, Singh B, Nagpal AK. Bioactivities of phytochemicals present in tomato. J Food Sci Technol. 2018;55(8):2833-49.https://doi.org/10.1007/s13197-018-3221-z PMid:30065393

5. Martí R, Leiva-Brondo M, Lahoz I, Campillo C, CebollaCornejo J, Roselló S. Polyphenol and L-ascorbic acid content in tomato as influenced by high lycopene genotypes and organic farming at different environments. Food Chem. 2018;239:14856. https://doi.org/10.1016/j.foodchem.2017.06.102 PMid:28873552

6. Ahmed FA, Sipes BS, Alvarez AM. Postharvest diseases of tomato and natural products for disease management. Afr J Agric Res. 2017;12(9):684-91.

7. Obafemi YD, Ajayi AA, Taiwo OS, Olorunsola SJ, Isibor PO Isolation of Polygalacturonase-producing bacterial strain from tomatoes (Lycopersicon esculentum Mill.). Int J Microbiol. 2019;2019:7505606. https://doi.org/10.1155/2019/7505606 PMid:30766603

8. Charles MT, Arul J, Charlebois D, Yaganza ES, Rolland D, Roussel D, et al. Postharvest UV-C treatment of tomato fruits: Changes in simple sugars and organic acids contents during storage. LWT Food Sci Technol. 2016;65:557-64. https://doi. org/10.1016/j.Iwt.2015.08.055

9. Ma L, Zhang M, Bhandari B, Gao Z. Recent developments in novel shelf-life extension technologies of fresh-cut fruits and vegetables. Trends Food Sci Technol. 2017;64:23-38. https:// doi.org/10.1016/j.tifs.2017.03.005

10. Amaechi EC, Ohaeri CC, Ukpai OM, Adegbite RA. Prevalence of parasitic contamination of salad vegetables in llorin, North Central, Nigeria. Momona Ethiopian J Sci. 2016;8(2):136-45. https://doi.org/10.4314/mejs.v8i2.3

11. Bello SI, Aminu D, Olawuyi OJ, Afolabi-Balogun NB, Lawal AO, Azeez $\mathrm{AH}$, et al. Antibiotic sensitivity of bacterial and fungal isolates from tomato (Solanum lycopersicum L.) fruit. Trop Plant Res. 2016;3(1):112-9.

12. Alegbeleye OO, Singleton I, Sant'Ana AS. Sources and contamination routes of microbial pathogens to fresh produce during field cultivation: A review. Food Microbiol. 2018;73:177-208. https://doi.org/10.1016/j.fm.2018.01.003 PMid:29526204

13. Obafemi YD, Ajayi AA, Olasehinde GI, Atolagbe OM, Onibokun EA. Screening and partial purification of amylase from Aspergillus niger isolated from deteriorated tomato (Lycopersicon esculentum Mill.) fruits. Afr J Clin Exp Microbiol. 2018;19(1):47-57. https://doi.org/10.4314/ajcem.v19i1.7

14. Lake IR. Food-borne disease and climate change in the United Kingdom. Environ Health. 2017;16(1):117. PMid:29219100

15. Javed A. Food borne health issues and their relevance to Pakistani society. Am Sci Res J Eng Technol Sci. 2016;26(4):235-51.

16. Zekar FM, Granier SA, Marault M, Yaici L, Gassilloud B, Manceau $C$, et al. From farms to markets: Gram-negative bacteria resistant to third-generation cephalosporins in fruits and vegetables in a region of North Africa. Front Microbiol. 
2017;8:1569

PMid:28883810

https://doi.org/10.3389/fmicb.2017.01569

17. European Food Safety Authority and European Centre for Disease Prevention and Control (EFSA and ECDC). The European Union summary report on trends and sources of zoonoses, zoonotic agents and food-borne outbreaks in 2017. EFSA J. 2018;16(12):e05500. https://doi.org/10.2903/j. efsa.2018.5500

18. Kilonzo-Nthenge A, Liu S, Hashem F, Millner P, Githua S Prevalence of Enterobacteriaceae on fresh produce and food safety practices in small-acreage farms in Tennessee, USA. J Consum Prot Food Saf. 2018;13(3):279-87. https://doi. org/10.1007/s00003-018-1172-y

19. Saksena R, Malik M, Gaind R. Bacterial contamination and prevalence of antimicrobial resistance phenotypes in raw fruits and vegetables sold in Delhi, India. J Food Saf. 2020;40(1):e12739. https://doi.org/10.1111/jfs.12739

20. Al-Kharousi ZS, Guizani N, Al-Sadi AM, Al-Bulushi IM. Antibiotic resistance of Enterobacteriaceae isolated from fresh fruits and vegetables and characterization of their AmpC $\beta$-lactamases. J Food Prot. 2019;82(11):1857$63 . \quad$ https://doi.org/10.4315/0362-028x.jpp-19-089 PMid:31609646

21. Bello OO, Oni MO, Bello JO, Bello TK. The incidence of extended-spectrum beta-lactamase (ESBL)-producing bacteria in salad vegetables in Ondo city, Nigeria. Asian Food Sci J. 2019;1:1-14. https://doi.org/10.9734/afsj/2019/v9i130003

22. Richter L, Du Plessis EM, Duvenage S, Korsten L. Occurrence, identification, and antimicrobial resistance profiles of extendedspectrum and AmpC $\beta$-lactamase-producing Enterobacteriaceae from fresh vegetables retailed in Gauteng Province, South Africa. Foodborne Pathog Dis. 2019;16(6):421-7. https://doi. org/10.1089/fpd.2018.2558

23. Olotu EJ, Aribisala JO, Oluyele O, Ojo OR, Olaniyi BO. Bacteriological and parasitological assessment of fruits and vegetables sold in Akoko South West Local government area of Ondo state Nigeria. Int Res J Gastroenterol Hepatol. 2020;1:11-20.

24. Al-Kharousi ZS, Guizani N, Al-Sadi AM, Al-Bulushi IM, Shaharoona B. Hiding in fresh fruits and vegetables: Opportunistic pathogens may cross geographical barriers. Int J Microbiol. 2016;2016:4292417. https://doi.org/10.1155/2016/4292417

25. Adekanle MA, Effedua $\mathrm{HI}$, Oritogun KS, Adesiji YO, Ogunledun A. A study of microbial analysis of fresh fruits and vegetables, in Sagamu markets South-West, Nigeria. Agrosearch. 2015;15(2):1-12. https://doi.org/10.4314/agrosh. v15i2.1

26. Adepoju AO. Post-harvest losses and welfare of tomato farmers in Ogbomosho, Osun state, Nigeria. J Stored Prod Postharvest Res. 2014;5(2):8-13. https://doi.org/10.5897/jsppr2014.0160

27. Izah SC, Aigberua AO. Microbial and heavy metal hazard analysis of edible tomatoes (Lycopersicon esculentum) in Port Harcourt, Nigeria. Toxicol Environ Health Sci. 2020;12(4):37180. https://doi.org/10.1007/s13530-020-00060-8

28. Adewuyi SA, Adekunle CP. Socio-economic determinants of tomato retail marketing in Ibadan Southwest Local Government area of Oyo State, Nigeria. Afr J Agric Sci. 2015;10(13):161924. https://doi.org/10.5897/ajar2015.9529

29. GizawZ. Publichealth risks related to food safety issues in the food market: A systematic literature review. Environ Health Prevent Med. 2019;24(1):68. https://doi.org/10.1186/s12199-019-0825-5 PMid:31785611

30. Meléndez-Martínez AJ, Stinco CM, Mapelli-Brahm P. Skin carotenoids in public health and nutricosmetics: The emerging roles and applications of the UV radiation-absorbing colourless carotenoids phytoene and phytofluene. Nutrients. 2019;11(5):1093.

\section{PMid:31100970}

31. Obeng FA, Gyasi PB, Olu-Taiwo M, Ayeh-Kumi FP. Microbia assessment of tomatoes (Lycopersicon esculentum) sold at some central markets in Ghana. Biomed Res Int. 2018;2018:6743826. https://doi.org/10.1155/2018/6743826

32. Oyedepo SO, Adeyemi GA, Olawole OC, Ohijeagbon OI, Fagbemi OK, Solomon R, et al. A GIS-based method for assessment and mapping of noise pollution in Ota metropolis, Nigeria. MethodsX. 2019;6:447-57. https://doi.org/10.1016/j. mex.2019.02.027

33. Mitruka BM. Methods of Detection and Identification of Bacteria. Boca Raton: CRC Press; 2017.

34. So W, Shurko J, Galega R, Quilitz R, Greene JN Lee GC. Mechanisms of high-level ceftolozane/ tazobactam resistance in Pseudomonas aeruginosa from a severely neutropenic patient and treatment success from synergy with tobramycin. J Antimicrob Chemother. 2019;74(1):269-71. https://doi.org/10.1093/jac/dky393 PMid:30295837

35. Clinical and Laboratory Standards Institute. Performance Standards for Antimicrobial Susceptibility Testing. $29^{\text {th }}$ ed., Vol. 29. Wayne, PA: Clinical and Laboratory Standards Institute; 2018. p. 320.

36. Singh RP, Jha P, Jha PN. The plant-growth-promoting bacterium Klebsiella sp. SBP-8 confers induced systemic tolerance in wheat (Triticum aestivum) under salt stress. J Plant Physiol. 2015;184:57-67. https://doi.org/10.1016/j.jplph.2015.07.002 PMid:26217911

37. NCBI Resource Coordinators. Database resources of the national center for biotechnology information. Nucleic Acids Res. 2018;46(D1):D8-13. https://doi.org/10.1093/nar/gks1189 PMid:29140470

38. Dasgupta CN, Singh VK, Nayaka S, Kishore S, Lavania S. Molecular phylogeny of a commercially important thermophilic microalga Chlorella sorokiniana LWG002615 and associated bacterium Aquimonas sp. NBRI01 isolated from Jeori thermal spring, Shimla, India. Nucleus. 2020;63:203-10. https://doi. org/10.1007/s13237-019-00286-z

39. Obayelu OA, Adegboyega OM, Sowunmi FA, Idiaye CO. Factors explaining postharvest loss of hot pepper under tropical conditions. Int J Veg Sci. 2021;2021:1-10. https://doi.org/10.108 0/19315260.2021.1879342

40. Obebe OO, Aluko OO, Falohun OO, Akinlabi KB, Onyiche TE. Parasitic contamination and public health risk of commonly consumed vegetables in Ibadan-Nigeria. Pan Afr Med J. 2020;36:126. https://doi.org/10.11604/pamj.2020.36.126.19364

41. Agbalaka PI, Ejinaka OR, Yakubu DP, Obeta UM, Jwanse RI, Dawet A. Prevalence of parasites of public health significance in vegetables sold in Jos metropolis, Plateau State, Nigeria. Am J Public Health. 2019;7(2):48-57.

42. El-Ramady HR, Domokos-Szabolcsy É, Abdalla NA, Taha HS, Fári M. Postharvest management of fruits and vegetables storage. In: Sustainable Agriculture Reviews. Cham: Springer; 2015. p. 65-152. https://doi.org/10.1007/978-3-319-09132-7_2

43. Mohan MG, Sutar RF, Mohan RJ. Impact of storage temperature $7^{\circ} \mathrm{C}$ and post-harvest pre-treatment on quality characteristics and storage life of tomato (Lycopersicon esculentum) fruits. Int J Agric Sci Res. 2017;7(4):23-30. https://doi.org/10.24247/ ijasraug20174

44. Tsang YP, Choy KL, Wu CH, Ho GT, Lam HY, Tang V. An intelligent model for assuring food quality in managing a multitemperature food distribution centre. Food Control. 2018;90:8197. https://doi.org/10.1016/j.foodcont.2018.02.030

45. Kayode RM, Afolayan AJ. Microbiological and chemical evaluation of decomposed open pollinated tomato (Lycopersicon esculentum) fruits in storage. J Pure Appl Microbiol. 2014;8(6):4441-9. 
46. Brasil IM, Siddiqui MW. Postharvest quality of fruits and vegetables: An overview. In: Preharvest Modulation of Postharvest Fruit and Vegetable Quality. Cambridge: Academic Press; 2018. p. 1-40. https://doi.org/10.1016/ b978-0-12-809807-3.00001-9

47. Chinedu SM, Enya E. Isolation of microorganisms associated with deterioration of tomato (Lycopersicon esculentum) and pawpaw (Carica papaya) fruits. Int J Curric Microbiol Appl Sci. 2016;3(5):501-12.

48. Iseppi R, de Niederhäusern S, Bondi M, Messi P, Sabia C. Extended-spectrum $\beta$-lactamase, AmpC, and MBL-producing gram-negative bacteria on fresh vegetables and readyto-eat salads sold in local markets. Microbial Drug Resist. 2018;24(8):1156-64. https://doi.org/10.1089/mdr.2017.0198

49. Dey M, Mokbul M, Ismail I, Alim SR. Identification of antibiotic resistant gram-negative bacteria in a popular street-food item (Chatpati) in Dhaka university campus, Bangladesh. Front Environ Microbiol. 2018;4(2):75. https://doi.org/10.11648/j. fem.20180402.15

50. Jung $D$, Rubin JE. Identification of antimicrobial resistant bacteria from plant-based food products imported into Canada. Int J Food Microbiol. 2020;1:08509. https://doi.org/10.1016/j. ijfoodmicro.2020.108509

51. Belay Z, Gelgelu E, Chala B. Assessment of microbiological quality and drug resistance patterns of raw vegetables irrigated with Hasassa River, West Arsi Zone, Oromia Region, Ethiopia. Afr J Microbiol Res. 2020;14(9):507-15. https://doi.org/10.5897/ ajmr2019.9205

52. Balali GI, Yar DD, Dela VG, Adjei-Kusi P. Microbial contamination, an increasing threat to the consumption of fresh fruits and vegetables in today's world. Int J Microbiol. 2020;2020:3029295. https://doi.org/10.1155/2020/3029295

53. Aggarwal D, Upadhyay SK, Kaur L, Kumar A, Bhalla H, Singh R. Assessment of microbial burden on vegetable salads for food safety and human health. Bull Pure Appl Sci Zool. 2020;39:1306. https://doi.org/10.5958/2320-3188.2020.00015.7

54. Nithya A, Babu S. Prevalence of plant beneficial and human pathogenic bacteria isolated from salad vegetables in India. BMC Microbiol. 2017;17(1):1-16. https://doi.org/10.1186/ s12866-017-0974-x

55. Callejón RM, Rodriguez-Naranjo MI, Ubeda C, HornedoOrtega R, Garcia-Parrilla MC, Troncoso AM. Reported foodborne outbreaks due to fresh produce in the United States and European Union: Trends and causes. Foodborne Pathog Dis 2015;12(1):32-38. https://doi.org/10.1089/fpd.2014.1821

56. Folster JP, Grass JE, Bicknese A, Taylor J, Friedman CR, Whichard JM. Characterization of resistance genes and plasmids from outbreaks and illness clusters caused by Salmonella resistant to ceftriaxone in the United States, 20112012. Microbial Drug Resist.2017;23(2):188-93. https://doi. org/10.1089/mdr.2016.0080 PMid:27828730

57. Akinduti PA, Olasehinde GI, Ejilude O, Taiwo OS, Obafemi YD. Fecal carriage and phylodiversity of community-acquired blaTEM enteric bacilli in Southwest Nigeria. Infect Drug Resist. 2018;11:2425-33. https://doi.org/10.2147/idr.s178243 PMid:30568469

58. Duvenage S, du Plessis E, Kgoale D, Ratshilingano M, Baloyi T, Richter $\mathrm{L}$, et al. Formal and informal spinach safety from farm to fork: A South African case study. In: IAFP European Symposium on Food Safety. United States: Global Association for Food Protection; 2019.

59. Hjikarim F, Dallal MM, Pourmand MR, Abdi M. An investigation of extended-spectrum $\beta$-lactamases (ESBLs) in Klebsiella isolated from foodborne outbreaks in Iran. Gene Rep. 2020;2020:100632. https://doi.org/10.1016/j.genrep.2020.100632 